\title{
Non-financial corporations: Changing accumulation pattern and relations with financial institutions
}

\section{ANNA ZĄBKOWICZ ${ }^{1}$}

The Jagiellonian University, Institute of Economics, Finance and Management

\begin{abstract}
The article refers to the phenomenon of the dissemination of financial logic in the management of joint stock companies, which basic activities are conducted outside the financial sector. This phenomenon has been observed in the United States since the eighties of the twentieth century and is also confirmed in the European Union, some Polish companies operating across borders included. Non-financial corporations are increasingly interested in profits derived from financial assets, financial institutions alike.

The article reviews literature in purpose to draw attention to new problems of control which result from the change mentioned in the title. In case of non-financial corporations undergoing the change controlling by financial institutions becomes elusive and illusory.
\end{abstract}

Paper type: review article

Keywords: corporate governance, economic interest, financialization, US corporations

\section{Introduction}

The phenomenon of acquiring financial logic in managing joint stock companies which basic activities are conducted outside the financial sector wins interest in American literature mainly since the nineties of the $20^{\text {th }}$ century. The carrier of this change are big corporations of American or Western-European origin. As they operate across borders, patterns and problems associated with the discussed phenom-

1 anna.zabkowicz@uj.edu.pl 
enon are transferred to the peripheral economies of the South, not missing the Eastern European EU member states. The effects are not limited to a new style of managing a multi-level stakeholder enterprise that is to corporate governance. Institutional changes in the domain of companies are transferred into state institutions, which in turn provide the framework for socio-economic policy in the countries concerned. According to Aoki (2001), the state constitutes of government and the rules that it (in part) sets and (with varying efficiency) enforces. It is perceived also as a sphere of political exchange between government and the private sector, the result of which is a certain order between them (Aoki, 2001, p. 152). That institutional order is subject to change in the domain of the state (polity) nowadays. Through various access channels corporations influence the decisions of the government. Dynamic processes of accumulation and of displacement lead over time to changes at the layer of economic system as well as at the layer of economic policy (more Ząbkowicz, 2009).

The article deals with the case of the USA as the one which is best documented. According to all the data it is in the United States where one should look for the beginning of the process under consideration. The context created by the broader economic policy is important, because interrelations between large business organizations and socio-economic policies seem to be bi-directional. Financialization of non-financial corporations in the United States is the outcome of a turn-about in macroeconomic policies, and of reforms initiated at the turn of the seventh and eighth decades of the $20^{\text {th }}$ century. This change was in the sake of maintaining competitiveness and ability to generate profits of domestic corporations. In the face of two oil shocks and the largest post-war recession in the seventies manufacturing corporations required restructuring. New conservative-liberal economic policies implemented by the Reagan's and Carter's administrations as well as by the Fed, chaired by Paul Volcker, were to make competitive position of US companies stronger (Panitch \& Gindin, 2005, p. 150). Favourable conditions for entrepreneurs were to be created by increasing the scope of free market through the deregulation of state-controlled sectors and through their privatization, and due to macroeconomic-policy focus on reducing tax and para-tax burdens, and on reducing inflation as well. These changes were accompanied by liberalization of finance, which was among other things meant to lower the barrier of demand for businesses. A surge in loans to the private sector (since the mid-seventies), and the increasing role of consumer credit in relation to disposable income (from the early nineties) could be observed (Lehman, 1997). The bank loans increasingly funded not only purchases of goods but also of variety of financial assets, with the latter leading to a series of price bubbles in stock and real estate markets, tolerated by the Fed because of the wealth effect (more Ząbkowicz, 2010). Corporations whose original domain was production became engaged in the leveraged purchases of financial assets, this is of stocks, debt securities, real estate, derivatives, etc. 
The topic of this article is the change in the accumulation pattern of manufacturing corporations, which involves growing share of income from trading financial assets and from lending. The change concerned meant revaluation of basic objectives of the organization as well as of relationships between the basic groups of stakeholders. Consequently, the hypothesis emerged on the new alliance between management of manufacturing corporations and management of financial institutions.

The article reviews literature in purpose to draw attention to new problems of control which result from the change mentioned in the title. The hypothesis is posed that the convergence of managers' interests both of non-financial corporations and of financial institutions could mean a weakening control, evenly in internal and external dimension. This situation may, among others, weaken incentives to promote quality management in non-financial companies.

\section{Management - new ideas and new institutional solutions ${ }^{2}$}

The growing share of exclusively financial transactions in generating non-financial corporations income seems to be the key to understanding the change in their behaviour, at least in the class of large multi-divisional organizations.

Changes in the income structure of manufacturing companies can be measured, using balance-sheet data for a sample of large companies, as Krippner (2005) does. She proposes an indicator that makes it clear that currently non-financial corporations in the USA are less reliant on their original domain of activity. Especially in the case of manufacturing companies shift in pattern of generating profits from operating activities to financing activities is evident. In 2001, income from financial operations generated by US industrial corporations almost equalled net income from operating activities (Krippner, 2005, p. 185). The former category that is portfolio income consists of interest, dividends and of income from asset trading, mainly share buybacks (Krippner, 2005, p. 174). The dimension of the phenomenon measured this way in the eighties and nineties of the twentieth century multiplied as compared to the fifties and the sixties and ranged at three to five times higher. Some studies also confirm the growing interest in non-production and non-trade activity of leading European corporations. For example, one can refer to the data on the increase in income from financial operations compared to net income concerning the leading companies in the food industry (Table 1). This group includes companies such as Danone, Nestle and Unilever (Palpacuer, Seignour, \& Vercher, 2008, pp. 5, 9).

2 This section contains excerpts of the article: The growing importance of income from financial transactions in non-financial corporations (financialization) - institutional context (Ząbkowicz, 2009). 
Table 1 Dividends and share buybacks as \% of cash flows, 1996-2000, food industry

\begin{tabular}{|c|c|c|c|}
\hline Year & $\begin{array}{c}\text { European corporations } \\
(n=11)\end{array}$ & $\begin{array}{c}\text { American corporations } \\
(n=8)\end{array}$ & $\begin{array}{c}\text { Together } \\
(n=19)\end{array}$ \\
\hline 1996 & 26.6 & 101.7 & 48.8 \\
\hline 1997 & 28.1 & 67.0 & 42.1 \\
\hline 1998 & 32.6 & 116.0 & 54.9 \\
\hline 1999 & 47.1 & 93.1 & 59.0 \\
\hline 2000 & 33.3 & 68.1 & 46.2 \\
\hline Average & 33.5 & 89.2 & 56.4 \\
\hline
\end{tabular}

Source: Palpacuer, 2008, p. 32.

The change in the pattern of accumulation captured in the referenced study is associated with changes in the system of coordination in the domain of corporations. Since the eighties of the twentieth century both in the United States and in Europe one can observe a process of installing corporate institutional arrangements that make boards of non-financial corporations inclined to gain revenues in the financial markets. ${ }^{3}$ Owing to these devices the phenomenon turns out to be broader than the current "technical" description could suggest. It develops along with changes in procedures for setting goals, in motivation systems, in controlling and in enforcement of tasks and obligations. For example, compensation of chief managers through stock options made their earnings dependable on the prices of shares of the managed company (Palpacuer et al., 2008, p. 4). Thus, the interests of corporate managers have become more consistent with the interests of shareholders. For similar reasons, boards of directors make decisions about engaging in programs of share buybacks. The activity of managers of non-financial companies is strongly oriented to reporting in accordance with the requirements of the financial markets. One of the examples is the implementation of the Economic Value Added Indicator, which was seen to have been introduced in the surveyed companies at the turn of the twentieth and twenty-first century (Palpacuer et al., 2008, p. 4). Generally speaking, the indicator contains the difference between company's gains from the operating activities and the remuneration of capital. The latter figure contains, among others, the return on capital expected by investors. Allowing profits to shareholders ex ante constitutes a breakthrough to the previous practice of calculating it ex post as the rest which remained after claims of stakeholders having been satisfied. Institutional devices of this kind have shaped management style known as a "shareholder view."

3 The same process has been observed since the end of the nineties in Japanese keiretsu conglomerates. 
The procedural rules (institutions) under consideration are rooted in a system of ideas, normally referred to as focused on shareholder value creation. The corporation is seen as a device for enrichment of its owners and/or as a bundle of contracts. In terms of the theory of transaction costs a company can be reduced to the sum of bilateral contracts between individuals who undertake rational and opportunistic decisions (Williamson, 1998). According to the agency theory and the theory of property rights (Alchian, 1977; Demsetz, 1967; Furubotn \& Pejovich, 1974) managers are salaried professionals whose job is to create value for shareholders. Human resources are treated like a commodity. If the price of an employee is not adequate to his or her contribution to value creation the company gets rid of him/ her (market-based human resources model). Likewise, relationships with other stakeholders, that is with managers of other companies, with banks, with suppliers, etc. become commodified.

This tangle of interests, institutions and ideas implies conduct different from the previously dominating focus on a stakeholder (so called stakeholder view) which manifested itself, among others, in cultivation of traditional business relationships with employees, with banks, etc. Basically, the shareholder view recommendation for strategic corporate management is to "downsize and distribute" (Lazonick \& O'Sullivan, 2000; Crotty, 2005). Downisizing relates primarily to employment and labour costs, yet the distribution relates primarily to corporate profits being divided among shareholders. The first recommendation contains lay-outs either transfer of jobs to other countries via direct investment or outsourcing of tasks to other companies. Profits flow to shareholders mainly in the form of dividends or in result of the stock exchange operations. The significance of stock-exchange in the model seems to be extraordinary. Due to acquisitions and hostile takeovers of control packets of shares the capital markets mobilize and motivate the managers. Accordingly, it is maintained that a commitment to create value for the owners is controlled by the market (market for corporate control).

Therefore, some authors hypothesize about a new alliance (Palpacuer, 2008). According to views close to the school of regulation the major decision-making is made by managers, and it is their job to decide both about strategy as well as about coalitions with other stakeholders. When mass production meant successful business strategy, then Fordism was on the top and the role of stakeholders in the company was acknowledged. At that time managers together with engineers and other white-collar employees formed part of the so-called technostructure (Palpacuer, 2008, pp. 5-6; Galbraith, 1973).

In the last decades of the $20^{\text {th }}$ century strategies, management styles as well as alliances were subject to change. Corporate managers "discovered" a strategy of global competition, which to a much greater degree relies on financial operations like foreign investment, mergers and acquisitions, etc. where the game is primarily about the ratio of stock prices. Consequently, they began to identify their own interests with shareholder value creation which involved an amendment of 
the rules of the game in the domain of businesses. It is emphasized that although the change has contributed to increasing convergence of interests of management with the interests of the owners of companies, strategy and coalitions are still a matter of choices made by corporate managers rather than a matter of influence of shareholders. Increased interest of management of non-financial companies in stock exchange-operations is combined with intense communication with financial analysts and brokers that is with investment managers; there were established procedures of meetings and consultations of the representatives of boards of nonfinancial corporations with agents of financial markets. Similarly, the growing debt makes good relations with banks even more important. In recent decades, preferences and attention of managers seem to have moved from the staff to investors, or more precisely, to financial institutions, that is banks and institutional investors (Boyer, 2000; Sklair, 1998).

\section{Relations with financial institutions - control or shared interest}

The issue of alliances includes into perspective power relations and group interests, and thus makes to cross the conventional boundaries of corporate governance. In this regard the following changes seem to be important as far as non-financial corporations concerned. First, the increased participation of representatives of financial institutions in the boards of these companies, which implies control issues. Secondly, manufacturing companies have become much more dependent on resources provided by banks and financial markets, which has an impact on the balance of power.

Literature on control issues does not rely on the simple distinction made by Berle and Means (1991) between shareholders and managers alone, but examines the impact which creditors, mainly banks, and other financial institutions, mainly institutional investors, exert on non-financial corporations. During the seventies of the twentieth century the issue of control with regard to non-financial companies was seen in the context of debt repayment strategy and of participation in mergers and acquisitions (Kotz, 1978). The role of banks as creditors was implied by the presence of their representatives in the corporate boards and stimulated research, to what extent, therefore, banks monitor and shape the behaviour of non-financial companies (Kotz, 1978; Mintz \& Schwartz, 1985; Mizruchi \& Sterns, 1994). Contemporarily, along with growing importance of financial markets in the strategy of large corporations, a growing share of institutional investors among major shareholders has been observed (Palpacuer, 2008, p. 3). Does this mean that one can defend the thesis that shareholder view was imposed by the financial sector's representatives present in the boards and general meetings of the non-finan- 
cial companies? The debate did not end in a clear decision (Mizruchi, 1996; Davis \& Thompson, 1994; Fligstein, 2002; Zorn, Dobbin, Dierkes, \& Kwok, 2004).

Some studies challenge the view that the presence of institutional investors among the major shareholders played role in financialization of non-financial corporations (Palpacuer, 2008 p. 3). Research on transnational corporations operating in food industry on a sample from the United States confirms the dominance of institutional investors among the largest shareholders (83\%) in the end of the last century. Such ownership structure could be a partly explanation to the more pronounced focus of management decisions on profits from financial operations. However, the hypothesis which seems to have a strong foundation in the American experience weakens if one looks closer at the distribution of property in the selected European companies. First, the role of institutional investors in the case of corporations from Europe is significantly lower (41\%), and, further, it decreases if the UK is excluded. Secondly, in those cases where the involvement of institutional investors is the lowest, the concentration of capital in the hands of other investors is extremely high. Those non-institutional shareholders of large corporations in mainland Europe are families and managers' partnerships. In short, in this group of companies, with Dutch Heineken and French LVMH included, institutional investors have very little to say. Even in the two companies previously referenced as the examples of financialization, this is in Nestle and Danone, the role of institutional investors seems to be incomparably smaller than in the surveyed US companies due to low concentration of capital in the hands of major shareholders. In the surveyed European companies, modelled according to the American design, such rules and controls gained popularity which channel managerial interest in non-financial corporations to stock markets and to other financial markets. With regard to this re-orientation of managerial decisions in non-financial corporations, however, the cited studies, at least in the European context, do not provide a strong foundation to the view that owner supervision of financial firms played an important role. At the same time they cast doubt on whether institutional investors were indeed the medium through which shareholder capitalism radiated from the United States to Europe. ${ }^{4}$

Nevertheless, there is no doubt that financial firms are to be found at the center of business connections of non-financial companies. While the facts of control are often difficult to be observed directly, dependence on the resources provided by financial institutions can be clearly demonstrated in numbers as well as via reconstruction of the historical process of change. We have just presented numbers

4 The shareholder view in management is popular in countries where business schools appear in considerable numbers. Opening up of the domestic financial markets in Western Europe in the eighties and in Central Europe in the nineties must be considered as one factor, and the recruitment of English-speaking managers for top positions in large corporations in continental Europe must be considered as another one (Palpacuer et al., 2008, p. 5). 
showing significant and growing share of the profits from financial transactions in the income of non-financial corporations. This trend means increasing dependence in income generation on the availability and price of credit as well as on conditions in other financial markets. Additionally, the balance sheets of this sub-sector, which constitutes the core of the US economy, have shown dramatic increases of payments to financial markets and of spending on share buybacks as related to adjusted net income (cash flow). Such changes in the balance sheets of non-financial corporations were a reflection of the developments in the credit markets and in the equities turnover in the nineties of the twentieth century. Namely, since 1982 the indebtedness of US non-financial corporations in relation to net assets has grown rapidly. The stock-exchange boom between 1994 and 1998 caused an unprecedented revaluation of their assets. Along with a relatively easy growth of their market value, experienced in the second half of the nineties, increased their sensitivity to the stock quotes; due to the growing debt their sensitivity to interest rates increased as well (Crotty, 2005, pp. 84, 98, 99).

The rising asset value allowed for massive borrowing, while the credit leverage, in turn, allowed for expanding purchases of securities and financial instruments. Effectively, along with growing debt grew also financial assets in relation to tangible assets (Crotty, 2005). Access to bank loans which are pledged by financial assets, stimulated demand and led to the stock market top, and, consequently, functioned as a leverage of income from financial operations to numerous actors. Banks offering credit to corporations (the larger the more reliable) earn interest. Corporations, taking advantage of available credit, invest in financial assets. Brokers in the financial markets take their commissions from rising turnover and see their earnings increasing. Rising demand induces increases in stock prices and improves the instruments and indicators related to them, stock options and EVA alike. Shares and other financial assets whose prices are rising are accepted as a pledge by banks who are willing to grant further loans. Firms being encouraged by income indicators, and being aware that the latter transform into interest of financial investors, use bank loans as before. As long as credit is available and the prices of financial assets are growing, the logic of leverage makes all parties of these transactions happy. Thus, both debtors (non-financial corporations) and creditors (banks) as well as institutional investors and financial markets intermediaries are interested in maintaining this situation.

In short, in the last decades of the twentieth century the mechanism of financial leverage allowed to multiply profits without undertaking production activities; thus industrial capital, which recognized the role of more aggressive finance in generating profits, went hand in hand with interests of financial capital (Panitch \& Gindin, 2005, p. 151; Krippner, 2005; Arrighi \& Silver, 1999). ${ }^{5}$

${ }^{5}$ The contemporary return to finance should be seen as a single precedent in the rich history of such rounds. 
Contemporary relations between non-financial firms and their partners from financial sector lead to the following conclusions. The problem of control of a manufacturing corporation by banks and other financial institutions which is developed in literature should not obscure the importance of convergence of interests between industrial and financial companies. Evidence that the financial companies control non-financial ones is rather difficult to grasp. However, some research confirms the importance of revenues from operations in money markets and from trading financial assets, which in the nineties accounted for nearly a half of incomes of non-financial corporations. This phenomenon seems to be the key to understanding the changes in their behaviour and strategies (Krippner, 2005, pp. 201202). However, data aggregated, for example at the sector level, rather mask the size of the change. The phenomenon of the growing importance of revenues from the exclusively financial transactions becomes clear at the level of companies as result of studying their financial statements. In total, the issue of who controls whom has lost its importance under new circumstances where both financial institutions and non-financial firms share interest in using financial leverage and in trading financial assets.

\section{Conclusions}

The article refers to the literature which indicates a significant interest of US nonfinancial corporations in the non-production and non-commercial activities. A measure of this phenomenon is the share of income from interest and turnover of financial assets as well as of dividends, which at the turn of the twentieth and twenty-first century accounted for almost half of the total income of the surveyed companies. We probably look at the change in pattern of accumulation, whereby the income from core operations of US non-financial corporations constitutes no longer the major income. Such change in structure of income of these companies is the starting point to the characteristics of fundamental change in the management style to be observed in the past decades. It seems to explain both the strategy and the new institutional solutions, referred to as the shareholder view management and the shareholder value creation. Corporate boards motivated in line with the ideology of shareholder value creation see their interests more aligned with the interests of shareholders, however, competitive strategy and coalitions of stakeholders seem to be still primarily a matter of the managerial choices.

The article refers to the fact of the increased participation of representatives of financial institutions in some boards of non-financial companies and raises the question whether this fact contributed to the managers' seeking revenues to more extent in the financial markets. The sources reviewed do not provide a strong evidence for the role of financial members of boards in the re-orientation of corporate 
governance. Importance should be given to the growing dependence on resources obtained in banks and in the financial markets rather than to the balance of power in corporate structures. The addiction stems from the fact that global competition implies a much greater reliance on financial operations, with share prices and credit leverage playing a pivotal role. There is no doubt that financial firms are situated at the very center of business connections of non-financial corporations. The balance sheets of the sub-sector confirm this finding, providing the indicators quoted in this paper, such as a significant share of profits from financial transactions in total income, an increase in financial assets in relation to physical assets, a relative increase in payments to the financial markets as well as in spending on share buybacks, increased indebtedness due to credit as related to the net assets, etc.

The review indicates the relatively new phenomenon of financialization of nonfinancial corporations and opens up questions about its possible consequences. The findings inspire to put forward a number of issues requiring further research.

Firstly, traditional roles in relations between manufacturing companies and financial intermediaries change. The growing share of profits from exclusively financial operations suggests that non-financial corporations less than in the past require borrowing in order to maintain the liquidity and continuity of the production and marketing processes, whereas banks consider respective loans to be a diminishing segment of their business.

Secondly, the interests of creditors and investors more than in the past seem to be consistent with interests of market-controlled companies, and come together on the financial markets. The increase in turnover of financial assets is the source of income to all participants of financial markets, this is to intermediaries in the transactions on commodities, securities and derivatives as well as to financial investors and to banks who support investment with credit, having become a major concern of non-financial corporations since several decades as well. The mechanism of leverage enables profits without production.

Thirdly, the reconfiguration of interests weakens oversight over the internal and external pro-effective processes in the domain of companies. Under new circumstances, both the creditors and financial investors seeking investment opportunities in the open market may be less interested in the productive performance, coming out from improvement in product quality, manufacturing process and competent management. Indeed, they attach importance to the financial indicators. The latter can often grow faster than the efficiency of core-business activities allows thanks to high profitability of exclusively financial operations. In the eye of creditors or "markets," the results due to increases in share prices or interest are likely to compensate the lack of managerial and/or engineering achievements. ${ }^{6}$

${ }^{6}$ This is what was probably meant by the CEO of the KGHM mining group, a Polish giant doing business internationally. Namely, he said that the company, which by nature of the industry generates high costs and makes profits only in the long run, thanks to appropriate asset portfolio can be, 


\section{References}

Alchian, A.A. (1977). Some economics of property rights. Il Politico, 30(4) [reprint Alchian A.A. (1965), Economic Forces at Work. Indianapolis: Liberty Press].

Aoki, M. (2001). Towards a Comparative Institutional Analysis. London: The MIT Press, Cambridge Ma.

Arrighi, G., \& Silver, B. (1999). Chaos and Governance in the Modern World System. Minneapolis: University of Minnesota Press.

Berle, A.A., \& Means, G.C. (1991). The Modern Corporation and Private Property. New York: Macmillan.

Boyer, R. (2000). Is a finance-led growth regime a viable alternative to Fordism? A preliminary analysis. Economy and Society, 29(1), 111-145.

Crotty, J. (2005). The neoliberal paradox: The impact of destructive product market competition and 'modern' financial markets on nonfinancial corporation performance in the neoliberal era. In G.A. Epstein (ed.), Financialization and the World Economy. Cheltenham, UK, Northampton MA: Edward Elgar Publishing, pp. 77-110.

Davis, G.F., \& Thompson, T.A. (1994). A social movement perspective on corporate control. Administrative Science Quarterly, 39(1), 141-173.

Demsetz, H. (1967). Toward a theory of property rights. American Economic Review, 57(2), 347-359.

Fligstein, N. (2002). The Architecture of Markets: An Economic Sociology of Twenty-first-century Capitalist Societies. Princeton: Princeton University Press.

Furubotn, E., \& Pejovich, S. (1974). The Economics of Property Rights. Cambridge: Ballinger Publishing.

Galbraith, J.K. (1973). Społeczeństwo dobrobytu \państwo przemysłowe. Warszawa: PIW.

Kotz, D. (1978). Bank Control of Large Corporations in the United States. Berkeley: University of California Press.

Krippner, G.R. (2005). The financialization of the American economy. Socio-economic Review, 3(2), 173-208.

Lazonick, W., \& O'Sullivan, M. (2000). Maximizing shareholder value: A new ideology for corporate governance. Economy and Society, 29(1), 13-35.

Lehman, M.B. (1997). The Wall Street Journal Workbook. Real World Economic Applications. Boston-Burr-Ridge-Dubuque-Madison-New York-San Francisco-St. Louis: Irwin McGrawHill.

Mintz, B., \& Schwartz, M. (1985). The Power Structure of American Business. Chicago: University of Chicago Press.

Mizruchi, M.S. (1996). What do interlocks do? An analysis, critique, and assessment of research on interlocking directorates. Annual Review of Sociology, 22, 271-298.

Mizruchi, M.S., \& Stearns, L.B. (1994). A longitudinal study of borrowing by large American corporations. Administrative Science Quarterly, 39(1), 118-140.

Palpacuer, F. (2008). Bringing the social context back in: Governance and wealth distribution in global commodity chains. Economy and Society, 37(3), 393-419.

Palpacuer, F., Seignour, A., \& Vercher, C. (2008). Financialization, globalization and white collar management in France: Towards a market-based HRM model in large corporations. British Journal of Industrial Relations, 49(3), 560-582.

however, well perceived by financial institutions. Anyway, "if the owner acts financial institutions alike, it bodes no good" (Wirth, 2015). 
Panitch, L., \& Gindin, S. (2005). Euro-capitalism and American Empire. In D. Coates (ed.) Varieties of Capitalism, Varieties of Approaches. Basingstoke - New York: Palgrave Macmillan UK, pp. 139-159.

Sklair, L. (1998). The transnational capitalist class and global capitalism: The case of the tobacco industry. Political Power and Social Theory, 12, 3-44.

Williamson, O.E. (1998). Ekonomiczne instytucje kapitalizmu. Firmy, rynki, relacje kontraktowe, Warszawa: Wydawnictwo Naukowe PWN.

Wirth, H. (10-11.10.2015). Nie możemy się bać, że coś się nam udało (interview). Gazeta Wyborcza.

Ząbkowicz, A. (2009). Wzrost znaczenia dochodów z operacji finansowych w korporacjach nie-finansowych (financialization) - kontekst instytucjonalny. Organizacja i Kierowanie, (2/136), 25-40.

Ząbkowicz, A. (2010). Ewolucja celu władzy monetarnej. Przypadek Rezerwy Federalnej Stanów Zjednoczonych. Polityka Gospodarcza, (83), 99-124.

Zorn, D., Dobbin, F., Dierkes, J., \& Kwok, M.S. (2004). Managing investors: How financial markets reshaped the American firm. In K. Knorr-Cetina, A. Preda (eds.), The Sociology of Financial Markets. New York: Oxford University Press, pp. 269-289.

\section{Note about the Author}

ANNA ZĄBKOWICZ - she works at the Jagiellonian University. Her current research interests focuses on economic policy, international competition and institutional economics. Graduate from the PMD67 at Harvard Business School in Boston. 